\title{
Sintering of sepiolite-rich by-products for the manufacture of lightweight aggregates: technological properties, thermal behavior and mineralogical changes
}

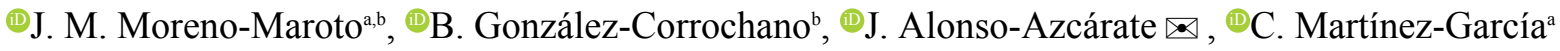 \\ a. Department of Chemical, Environmental and Material Engineering, Higher Polytechnic School of Linares, University of Jaen (Jaén, Spain) \\ b. University of Castilla-La Mancha. Department of Physical Chemistry, Faculty of Environmental Sciences and Biochemistry (Toledo, Spain) \\ jacinto.alonso@uclm.es
}

Received: 01 May 2020 Accepted: 15 September 2020 Available on line: 10 March 2021

\begin{abstract}
A sepiolite mining by-product (SEP) has been studied as major component for lightweight aggregate (LWA) manufacture. Pellet bursting during firing was avoided by the addition of $2.5 \mathrm{wt} \%$ of thermoplastic waste $(\mathrm{P})$ and $2.5 \mathrm{wt} \% \mathrm{P}+$ $2.5 \mathrm{wt} \%$ carbon fiber residue (FC) in powder form. The mixtures were pelletized and then sintered at $1225^{\circ} \mathrm{C}$ for 4 minutes in a rotary kiln. Highly porous white LWAs with good mechanical strength were produced. A mineralogical study revealed the formation of amorphous phase $(>50 \%)$ and minor proportions of enstatite, protoenstatite and diopside. Quartz was the only inherited mineral, appearing in the form of isolated phenocrysts within a general porphyritic texture. The result of this study suggests the promising use of sepiolite (whether or not in residue form) for the manufacture of high quality LWAs.
\end{abstract}

KEYWORDS: Aggregate; Ceramic; Waste treatment; X-ray Diffraction (XRD); Sepiolite.

Citation/Citar como: Moreno-Maroto, J.M.; González-Corrochano, B.; Alonso-Azcárate, J.; MartínezGarcía, C. (2021) Sintering of sepiolite-rich by-products for the manufacture of lightweight aggregates: technological properties, thermal behavior and mineralogical changes. Mater. Construcc. 71 [341], e241 https://doi.org/10.3989/mc.2021.05620

RESUMEN: Sinterización de subproductos ricos en sepiolita para la fabricación de áridos ligeros: propiedades tecnológicas, comportamiento térmico y cambios mineralógicos. Se ha investigado la fabricación de áridos ligeros (LWAs) a partir de subproductos de la extracción de sepiolita (SEP). Durante la cocción, el estallido de los pellets se evitó mediante la adición de $2.5 \mathrm{wt} \%$ de residuo de plástico (P) y $2.5 \mathrm{wt} \%$ de $\mathrm{P}+2.5 \mathrm{wt} \%$ de residuos de fibra de carbono (FC), ambos en forma de polvo. Las mezclas fueron peletizadas y sinterizadas en horno rotatorio a $1225^{\circ} \mathrm{C}$ durante 4 minutos. Se obtuvieron LWAs blancos, altamente porosos y con buena resistencia mecánica. Un estudio mineralógico reveló la formación de fase amorfa (>50\%) y proporciones menores de enstatita, protoenstatita y diópsido. El único mineral heredado fue el cuarzo, apareciendo en forma de fenocristales aislados dentro de una textura porfídica. Los resultados obtenidos sugieren que la sepiolita (ya sea en forma de residuo o no) puede tener un uso prometedor en la fabricación de LWAs de alta calidad.

PALABRAS CLAVE: Áridos; Cerámica; Tratamiento de residuos; Difracción de rayos-x (DRX); Sepiolita.

Copyright: (C2021 CSIC. This is an open-access article distributed under the terms of the Creative Commons Attribution 4.0 International (CC BY 4.0) License. 


\section{INTRODUCTION}

Sepiolite is a fiber micro-channel structured hydrated magnesium silicate, which due to its high adsorption and physicochemical potential is very valuable in many industrial sectors (1). Despite its broad applicability, sepiolite has been, in general terms, poorly studied in the ceramic industry, perhaps because when heated to common sintering temperatures (generally $>1100^{\circ} \mathrm{C}$ ), its particular properties tend to be significantly lost (2). However, different examples of sepiolite sintering into worthwhile ceramics can be found in the bibliography.

Some of the earliest evidence of the effective use of sepiolite as a substitute for kaolin in porcelain mixtures dates from the late 17 th and early 18 th centuries (3). Ran et al. (4) demonstrated that the addition of $2 \mathrm{wt} \%$ sepiolite improves the mechanical response in bone china bodies sintered from 1150 to $1250^{\circ} \mathrm{C}$. A similar outcome was previously obtained by Li et al. (5) when sepiolite was added to the dough intended to be fired into sanitary bodies. Likewise, it has been possible to sinter cordierite-based ceramics, whose industrial application is widespread in several sectors, from sepiolite at temperatures in the range $1200-1300^{\circ} \mathrm{C}(6,7)$. Another example of application of sepiolite in ceramics is found in the study by Suárez et al. (8), who were able to prepare $\mathrm{TiO}_{2}$-sepiolite ceramic hybrid plates to evaluate their performance in the photocatalytic degradation of trichloroethylene.

However, there has been no prior evidence of the use of sepiolite as a key component in the manufacture of lightweight aggregates (LWAs) until the publications of Moreno-Maroto et al. (9-11). LWAs are granular materials of high porosity, low density and good mechanical strength that are generally sintered by thermal shock, unlike the gradual heating conducted on traditional ceramics. Because of their properties, LWAs are very interesting to be applied in concrete production, in the agricultural sector and/or in civil and environmental engineering.

In the first two studies by Moreno-Maroto et al. $(9,10)$ cited above, the authors added a proportion of $10 \mathrm{wt} \%$ of a plant-rejected sepiolite (the same variety of the present research) for the sole purpose of conferring workability to a low plasticity granitic marble sludge. Small amounts of thermoplastic residues (9) and carbon fiber powder (10) were also applied to examine their ability to promote expansion (better results were obtained with carbon fiber). In a more recent study, a similar criterion has been followed in the manufacture of LWAs from wastes contaminated with heavy metals, again demonstrating the suitability of sepiolite rejects as a binder even in low proportions (11).

Therefore, as sepiolite use in low percentages has already been proven in the works cited above (9-11), the objective of the present research is to determine the applicability of a rejected sepiolite (theoretically not marketable) when used as a main component in the manufacture of LWAs. It is important to note that Spain is the largest producer of sepiolite, representing around $95 \%$ of the world's annual production (12). The production of sepiolite in Spain has remained within fairly steady limits in the last years, ranging between 500-600 thousand tonnes per year (13), a volume that is far above the estimated 10 thousand tonnes for Turkey, the other producer (14). The processing of this clay generates large volumes of rejected material which, although inert (code 0104 09: waste sand and clays), according to the list of wastes of the Commission Decision 2014/955/EU (15), may entail a negative landscape impact.

Through the production of lightweight aggregates, this research aims to find a solution for the large amounts of material rejected in the extraction plant for this type of clay. The role of thermoplastic and carbon fiber residues as additives will also be assessed.

\section{MATERIALS AND METHODS}

\subsection{Raw material sampling and preparation}

The sepiolite waste (SEP) was provided by the clay mining company Tolsa, S.A. (Vallecas plant, Spain), which usually trades this kind of clay as a pet litter absorbent. SEP was rejected at the plant as its aggregate size (about $<1 \mathrm{~mm}$ ) was not suitable for the market. According to the information given by the manufacturer, this type of sepiolite by-product is the one generated in greater quantities in the plant and therefore tends to be very homogeneous over time. Despite not being dangerous, from an environmental point of view, the valorization of this waste could suppose not only a reduction of the negative impact on the landscape generated by the large piles of rejected material, but also the use of a material with excellent physical-chemical properties, as an alternative to the exploitation of natural raw materials. After oven-drying at $60^{\circ} \mathrm{C}$ for $72 \mathrm{~h}$ to ensure that the material was perfectly dry (constant weight), SEP was milled to $<200 \mu \mathrm{m}$ (16) with a $\operatorname{Restch}^{\circledR}$ SK 100/C Spezialstahl arm mill.

The thermoplastic material $(\mathrm{P})$ was a linear polyethylene-hexene copolymer, which was ground below $0.5 \mathrm{~mm}$ under controlled temperature conditions, in accordance with Moreno-Maroto et al. (9). The carbon fiber residue (FC) was generated and supplied by the company ICSA-Aernnova (Toledo, Spain), specialized in the manufacture of aeronautical components based on carbon fiber composites. To facilitate the addition of the material in the mixtures, also FC was ground below $0.5 \mathrm{~mm}$, again in line with the methodology indicated in a previous work of the authors (10). As explained above for 
SEP, in the cases of FC and P, the wastes generated are very homogeneous in terms of composition, structure and properties, being almost invariable over time.

\subsection{Raw material characterization}

Below are listed the parameters measured in the characterization of the raw materials, as well as the method and/or instrument of measurement together with the corresponding references:

- Relative density $\left(\rho_{\mathrm{R}}\right)$ : AccuPyc ${ }^{\mathrm{TM}} 1330 \mathrm{He}$ pycnometer (17)

- Particle size distribution: Coulter ${ }^{\circledR}$ LSTM 230 laser diffraction analyzer (18-20) and ordinary sieving.

- Specific surface area (SSA): Methylene blue spot test $(21,22)$.

- Chemical composition: Inductively coupled plasma-atomic emission spectroscopy (ICPAES, Thermo Electron 6500 ICAP). Previous fusion with lithium metaborate and dissolving in acidic medium (23).

- Loss on ignition (LOI): muffle-firing $\left(1100^{\circ} \mathrm{C}\right.$ for $24 \mathrm{~h}$ ).

- Chemical suitability for bloating: Criterion 1. Recalculation of percentages of $\mathrm{Al}_{2} \mathrm{O}_{3}, \quad \mathrm{SiO}_{2}$ and flux oxides ( $\sum$ Flux = $\mathrm{K}_{2} \mathrm{O}+\mathrm{Na}_{2} \mathrm{O}+\mathrm{CaO}+\mathrm{MgO}+\mathrm{FeO}+\mathrm{Fe}_{2} \mathrm{O}_{3}$ ) and plotting in the Riley (24) diagram. Criterion 2. Calculation of the $\mathrm{SiO}_{2} / \sum$ Flux ratio (25).

- Carbon content (total (TC), organic (OC) and inorganic (IC) carbon): Shimadzu ${ }^{\circledR}$ TOC- $\mathrm{V}_{\mathrm{CSH}}$ analyzer.

- Atterberg limits, classification and maximum toughness: Liquid limit (LL) by Casagrande cup method (26). Plastic limit (PL) by bending test (27-29). Plasticity index (PI) calculated as: $\mathrm{PI}$ $=$ LL-PL (30). Classification according to Moreno-Maroto and Alonso-Azcárate (31) and Gippini (32) charts on plasticity and texture. Maximum toughness $\left(T_{\max }, \mathrm{kJ} / \mathrm{m}^{3}\right)$ :

$T_{\max }=[(\mathrm{PI} / \mathrm{LL})-0.3397] / 0.0077$ (31).

- Optimal moisture content $\left(\mathrm{W}_{\mathrm{OP}}\right)$ for pelletizing: $\mathrm{PL} \times 1.234$ (29).

- Thermal behavior: DSC-TGA; SDT Q600 TA INSTRUMENTS (platinum crucible, air atmosphere, $20^{\circ} \mathrm{C} / \mathrm{min}$, maximum temperature: $\left.1200^{\circ} \mathrm{C}\right)$.

\subsection{Formulation of mixtures}

The final mixtures were formulated on the basis of the characteristics of the raw materials, in con- junction with previous testing conducted in a Nannetti ${ }^{\circledR}$ TOR-R 120-14 tubular rotary kiln (used to sinter the LWAs).

In Table 1 , it is observed that SEP presented a meaningful SSA due to its small grain size (Figure 1), especially after milling $\left(343.3 \mathrm{~m}^{2} / \mathrm{g}\right)$, which resulted in a very high plasticity (Table 1 and Figure 2). Once oven-dried, it was observed that SEP was able to adsorb about $10 \mathrm{wt} \%$ of water from the ambient humidity. Previous trials in the rotary kiln showed that SEP was not adequate (without any additive) for LWA manufacture by itself, since the pellets burst in the kiln preheating zone very quickly. The reason is thought to be that the porosity of the SEP pellet is too low to allow a rapid release of water vapor outwards, leading to relatively high internal pressures. The addition of $2.5 \mathrm{wt} \%$ of $\mathrm{P}$ and $2.5 \mathrm{wt} \% \mathrm{P}+2.5 \mathrm{wt} \%$ FC (SEP-P and SEP-PFC in Table 1, respectively) prevented the pellet from bursting, so these two mixtures were finally selected for LWA manufacturing. The main properties of the mixtures associated with particle size distribution, $\rho_{\mathrm{R}}$, chemical composition, SSA, carbon content and plasticity were also measured by applying the same protocols previously indicated for the raw materials. Additional 24-hour LOI tests were performed at the selected firing temperature $\left(1225^{\circ} \mathrm{C}\right)$.



\subsection{Manufacture of the lightweight aggregates}

The manufacturing process of the LWAs was carried out according to the following steps:

i. Preparation of the mixtures shown in Table 1.

ii. Addition of the water corresponding to $\mathrm{W}_{\mathrm{OP}}$ (Table 1) and kneading.

iii. Maceration for $72 \mathrm{~h}$ in a hermetically sealed bag.

iv. Extrusion using a Nannetti ${ }^{\circledR}$ laboratory-scale pneumatic extruder. 
v. Pelletizing by hand into spherical granules of approximately $10.3 \mathrm{~mm}$.

vi. Drying: $48 \mathrm{~h}$ at room temperature $+48 \mathrm{~h}$ at $105^{\circ} \mathrm{C}$. The diameter of the dry pellets was $\sim 7.9 \mathrm{~mm}$, which represents a shrinkage by ovendrying of about $23.2 \%$.

vii. Firing: Several batches of 25 pellets were sintered. The equipment used was a Nannetti ${ }^{\circledR}$ TORR 120-14 tubular rotary kiln. The specific firing conditions for the SEP mixtures were established by "trial and error" pre-tests in line with previous studies (9-11):

- Tube rotation speed: $2.5 \mathrm{rpm}$.

- Preheating: $400-600^{\circ} \mathrm{C} ; 20$ seconds; entry zone of the kiln tube.

- Sintering: $1225^{\circ} \mathrm{C} ; 4 \mathrm{~min}$; middle section of the kiln tube.

- Cooling: Fast quenching at room temperature (around $25^{\circ} \mathrm{C}$ ).

\subsection{Characterization of the lightweight aggregates}

\subsubsection{Physical and mechanical characteristics}

The measured parameters relating to the physical and mechanical properties in LWAs, together with the methods used and their references, are as follows:

- LOI during kiln firing and preheating: Weight difference between the fired and the unfired specimens in a batch (25 granules).

- Bloating index (BI): Average percentage change in diameter experienced by the specimens in a batch because of firing (25).

- Loose bulk density $\left(\rho_{B}\right)$ : In accordance with EN-1097-3 (33).

- Particle density $\left(\rho_{\mathrm{A}}\right)$, skeleton density $\left(\rho_{\mathrm{S}}\right)$ and water absorption after $24 \mathrm{~h}$ of immersion $\left(\mathrm{WA}_{24}\right)$ : According to Annex $\mathrm{C}$ of the EN-1097-6 (34) standard and De Santiago Buey and Raya García (17).

- Relative density of the aggregate solid phase $\left(\rho_{\text {solid }}\right)$ : three specimens milled below $53 \mu \mathrm{m}$ $\left(\right.$ Retsch $^{\circledR}$ RM 100 rotary agate mill) and $\rho_{\text {solid }}$ measurement using an AccuPyc ${ }^{\mathrm{TM}} 1330$ helium pycnometer.

- Total porosity $\left(P_{T}\right)$, open porosity $\left(P_{O}\right)$ and closed porosity $\left(P_{C}\right)$ : Based on De Santiago Buey and Raya García (17) and Bernhardt et al. (35) approaches, using the results from $\rho_{A}, \rho_{S}$ and $\rho_{\text {solid }}$.
- Void percentage $(H)$ : estimation using $\rho_{\mathrm{B}}$ and $\rho_{\text {solid }}(9)$.

- Single aggregate crushing strength $(S)$ : Device employed: Nannetti ${ }^{\circledR}$ FM 96 press. Calculation of $\mathrm{S}$ as stated by Yashima et al. (36) and Li et al. (37), in this case inferred from the testing of 25 specimens of the same batch.

\subsubsection{Mineralogy and glass formation}

The study of the mineralogy and the glass formation was performed by XRD with a PANalytical ${ }^{\circledR}$ $X^{\prime}$ Pert Pro model diffractometer in accordance with Moreno-Maroto et al. (38) for quantitative analysis on LWAs. A few aggregates were ground to obtain a powder of $<53 \mu \mathrm{m}$ using a rotary agate mill. An amount of $25 \mathrm{wt} \%$ of the alumina standard reference material SRM 676a (39) was added to each sample. Then the powder was mixed until complete homogenization by shaking at 30 cycles/s for $5 \mathrm{~min}$ in a $\operatorname{Restsch}^{\circledR}$ MM 200 agate-container ball mill. The mineralogy was determined by XRD under the following conditions: $45 \mathrm{kV}, 40 \mathrm{~mA}, \mathrm{CuK} \alpha$ radiation and a system of slits (soller - mask- divergence antiscatter) of $0.04 \mathrm{rad}-10 \mathrm{~mm}-1 / 8^{\circ}-1 / 4^{\circ}$ with a $\mathrm{X}^{\prime}$ celerator detector. In order to obtain quantitative results of the crystalline and amorphous phases, the resulting diffractograms were refined by Rietveld method (40-42). Based on the quantity of SRM 676a added, the amorphous content was calculated simply by difference. The same route was carried out for the raw materials, but in this case no alumina was used.

\subsubsection{Texture and microstructure}

The texture of the sintered LWAs was observed by thin-section polarized light microscopy (TSPLM): $30 \mu \mathrm{m}$ thick slices (43) were embedded in an epoxy resin and studied with a Kyowa ${ }^{\circledR}$ petrographic transmitted-light microscope. Both planepolarized light (PP) and crossed-polarizers (CP) were applied for the observations. In addition, after gold coating, the internal microstructure was studied by scanning electron microscopy (SEM) using a JEOL JSM-6400 microscope $(20 \mathrm{kV})$ together with an energy-dispersive X-ray analyzer (EDX) for semi-quantitative chemical analysis.

\section{RESULTS AND DISCUSSION}

\subsection{Raw materials characteristics and suitability for LWA production}

According to the results of Table 1 and Figure $2 \mathrm{a}$, the sepiolite studied is highly plastic, with LL of 171.1 and $\mathrm{PI} / \mathrm{LL}$ ratio of 0.56 , yielding a $T_{\max }$ of $28.9 \mathrm{~kJ} / \mathrm{m}^{3}$. When mixed with $\mathrm{FC}$ and $\mathrm{P}$ (which 
Sintering of sepiolite-rich by-products for the manufacture of lightweight aggregates: technological properties, thermal behavior and mineralogical changes $\bullet$

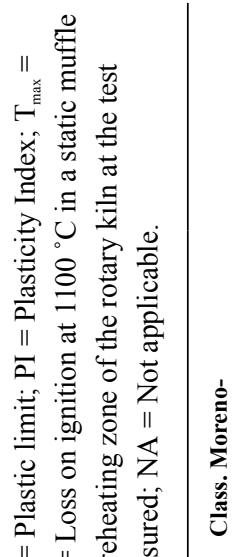

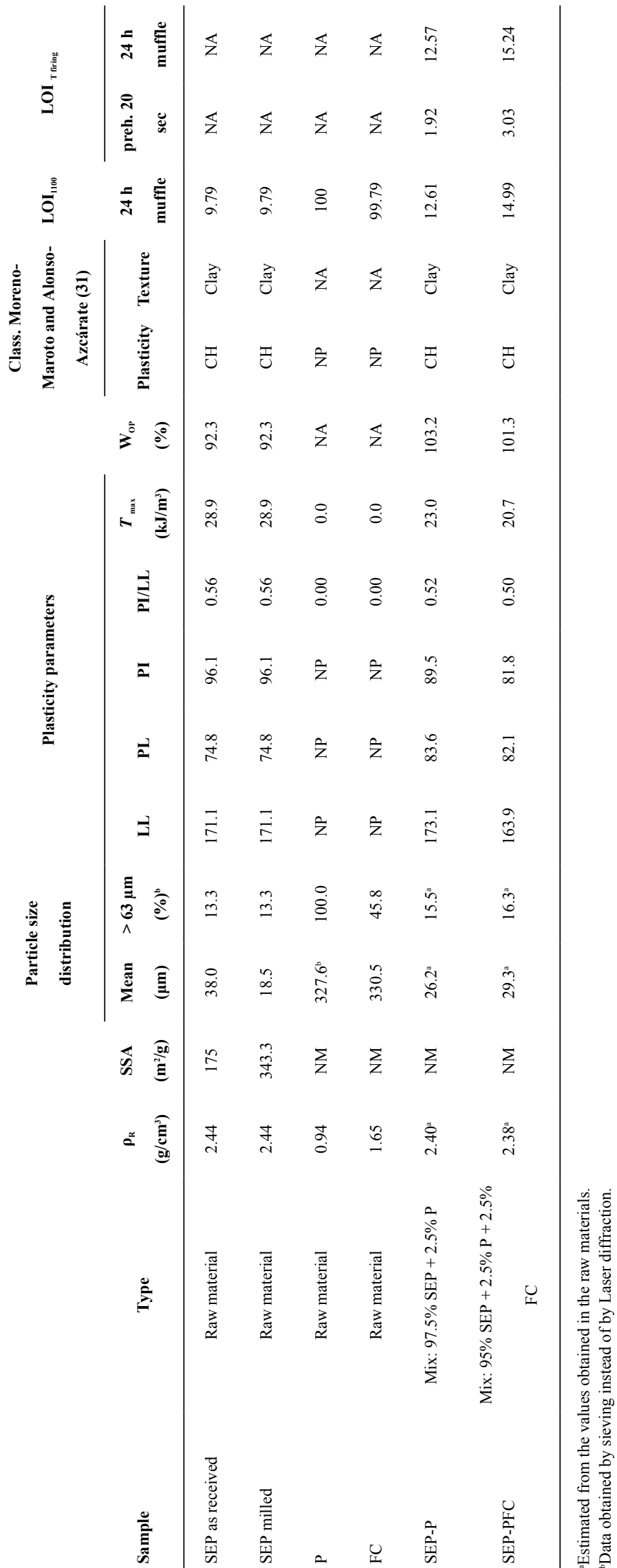


(a)

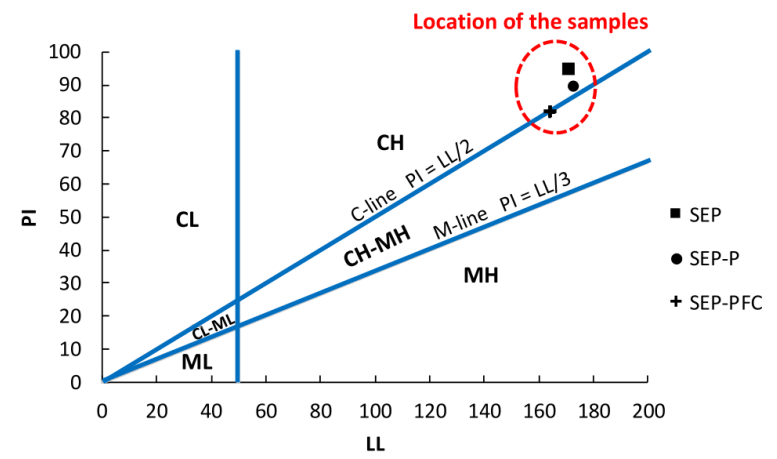

(b)

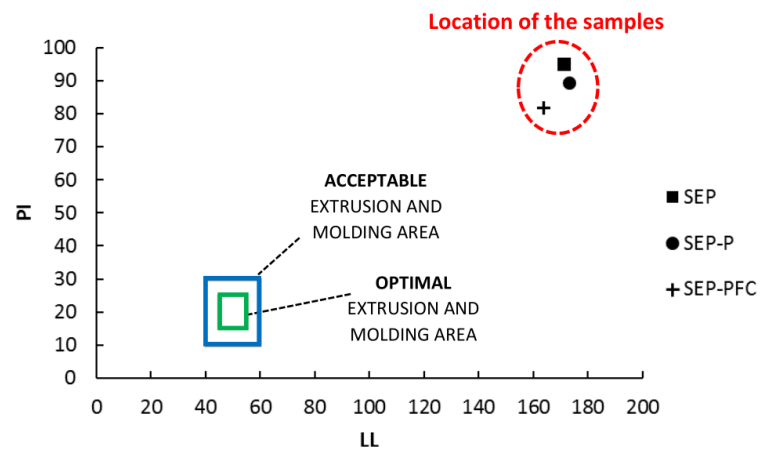

FIGURE 2. Location of SEP, SEP-PFC and SEP-P in the plasticity charts of (a) Moreno-Maroto and Alonso-Azcárate (31) and (b) Gippini (32)

are nonplastic), the plasticity diminishes slightly due mainly to a small increase in PL. Consequently, $T_{\max }$ values are 20 and $23.7 \mathrm{~kJ} / \mathrm{m}^{3}$ for SEP-P and SEP$\mathrm{PFC}$, respectively, figures that are in the same order as other ceramic clays studied (44). Thus, both the original sepiolite and the resulting mixtures are classified as clay-textured $\mathrm{CH}$ materials (31), because in addition to their significant plasticity, their sand content is low (13-16\%). Although their location is far from the Gippini (32) areas (Figure 2b), the toughness results point out that the materials could be suitable for LWA production.

Expanded LWA is formed by the development of a mineral matrix with a viscosity suitable for retaining the gases released from negligible amounts of certain gas-generating components (45). To achieve such conditions, not only is an adequate heating ramp required (usually sudden heating), but the material must also have appropriate chemical, mineralogical and particle size properties for the process of pore formation and bloating.

According to its chemical characteristics, SEP would not be suitable for retaining gases because its oxide composition is located outside the Riley (24) area (Figure 3) and the $\mathrm{SiO}_{2} / \sum$ Flux ratio is less than 2 (Table 2) (25). Likewise, if the limits of Cougny (46) on particle size distribution are considered (Figure 1), again none of the raw materials under study would be theoretically adequate for LWA manufacturing.

Based on the LOI data in Table 2 (LOI $\sim 10 \%$ ), SEP can produce an important volume of gas when heated. However, the percentages of $\mathrm{OC}$ and IC are relatively low $(0.44 \%$ and $0.41 \%$, respectively; Table 2). Consequently, their contribution to gas release is not expected to be significant. According to the XRD data (Table 3 and Figure 4), the carbonates are calcite and dolomite $(2.6 \%$ and $2.4 \%$, respectively), while other mineral species capable of generating gases in this sample are phyllosilicates, mainly smectite and sepiolite $(37.8 \%$ and $30 \%$, respectively).

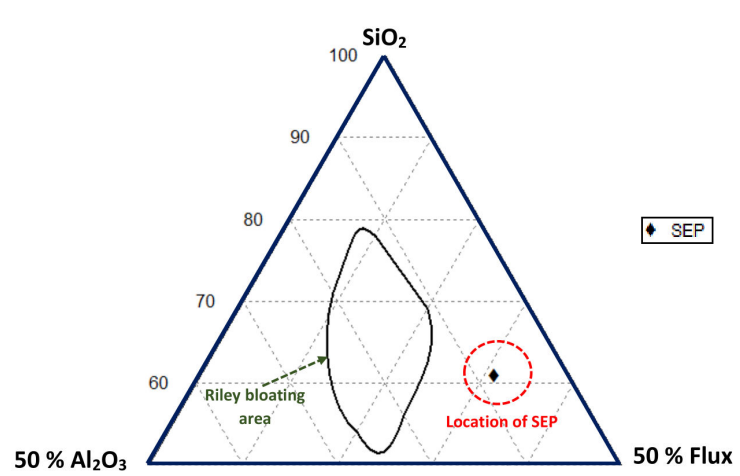

\footnotetext{
FIGURE 3. Location of SEP sample in the Riley diagram (24) on the theoretical suitability for bloating according to the chemical composition. SEP$\mathrm{P}$ and SEP-PFC have the same location as SEP.
}

According to the DSC-TGA graphs in Figure 5a, the most important loss of mass takes place at temperatures below $700^{\circ} \mathrm{C}$. Previous studies $(1,2,47)$ show that this phenomenon is closely related to the release of hygroscopic, zeolitic and coordinated water. On the other hand, and based on the same references cited above, the dehydroxylation of sepiolite and montmorillonite explain the LOI at the temperatures ranging $700-850^{\circ} \mathrm{C}$. These reactions are usually accompanied by the release of gaseous water molecules, although according to Heller-Kallai et al. (48), $\mathrm{H}_{2}$ could also be formed. As the percentages of calcite and dolomite are low $(<3 \%$, Table 3$)$, it is highly likely that their peaks cannot be detected in Figure 5a, because they have probably been overshadowed by those of the phyllosilicates.

On the other hand, and in accordance with Moreno-Maroto et al. (9-11), P and FC practically decompose at $100 \%$, giving rise to gases that could favor the development of a porous structure (Table 2 and Figure 5b, c). Similarly, the exothermic decomposition suffered by their components is remarkable (Figure 5b, c), which is in agreement with the biblio- 
TABLE 2. Carbon content and chemical composition results. $\mathrm{TC}=$ Total carbon; $\mathrm{IC}=$ Inorganic carbon; OC $=\mathrm{Organic}$ carbon;

$\mathrm{LOI}_{1100}=$ Loss on ignition at $1100^{\circ} \mathrm{C}$ (same values to those $\mathrm{LOI}_{1100}$ results represented in Table 1 ); $\sum$ Flux $=$ Sum of fluxing

oxides. All the numerical results are expressed in percentage, $\%$, but $\mathrm{SiO}_{2} / \sum$ Flux ratio (dimensionless). NA = Not applicable.

\begin{tabular}{|c|c|c|c|c|c|c|c|c|c|c|c|c|c|c|}
\hline \multirow[b]{2}{*}{ Sample } & \multicolumn{3}{|c|}{ Carbon content } & \multirow[b]{2}{*}{$\mathrm{SiO}_{2}$} & \multirow[b]{2}{*}{$\mathrm{Al}_{2} \mathrm{O}_{3}$} & \multicolumn{6}{|c|}{ Fluxing oxides } & \multirow[b]{2}{*}{$\mathrm{TiO}_{2}$} & \multirow[b]{2}{*}{$\mathbf{L O I}_{1100}$} & \multirow[b]{2}{*}{$\begin{array}{l}\mathrm{SiO}_{2} / \\
\sum \text { Flux }\end{array}$} \\
\hline & TC & IC & OC & & & $\begin{array}{l}\mathrm{FeO}+ \\
\mathrm{Fe}_{2} \mathrm{O}_{3}\end{array}$ & $\mathrm{Na}_{2} \mathrm{O}$ & $\mathrm{K}_{2} \mathrm{O}$ & $\mathrm{CaO}$ & MgO & $\mathbf{P}_{x} \mathbf{O}_{x}{ }^{b}$ & & & \\
\hline SEP & 0.85 & 0.41 & 0.44 & 54.8 & 7.2 & 2.0 & 0.5 & 1.6 & 2.0 & 21.9 & 0.1 & 0.3 & 9.79 & 1.96 \\
\hline $\mathrm{FC}$ & 82.11 & 0.00 & $82.11^{\mathrm{a}}$ & NA & NA & NA & NA & NA & NA & NA & NA & NA & 99.79 & NA \\
\hline$P$ & 90.37 & 0.00 & 90.37 & NA & NA & NA & NA & NA & NA & NA & NA & NA & 100 & NA \\
\hline
\end{tabular}

a Apart from the organic compounds from the epoxy resin, this result is mainly represented by inorganic pure carbon fibers which are also oxidable at high temperatures in air atmosphere

${ }^{\mathrm{b}}$ Sum of all oxides of phosphorous

graphy (49-55). This aspect may also be a key point in the development of a viscous matrix.

Traditionally it has been thought that in order for LWA to expand, it is important to avoid massive loss of gases during the heating of the material (56). However, recent research by Moreno-Maroto et al. (45) refutes this idea, showing that bloating occurs at a stage when more than $99 \%$ of the gas has been lost to the atmosphere, so that the pores of the aggregate develop from negligible amounts of gas. Therefore, the application of a thermal shock is not so much intended to prevent the incipient loss of gas, but rather to favor reducing conditions inside the aggregate, leading to the development of a viscosity in which pores can be formed from the available gas.

Similarly, despite the faint results related to particle size distribution and chemical composition, the suitability of the studied materials for LWA production will be examined in the following sections according to experimental findings, which show the actual behavior of the materials beyond their theoretical feasibility.

\subsection{Technological characteristics of the LWAs developed in this study}

Figure 6 shows an overview of the outer face and the core of the LWAs, whose main technological properties are presented in Table 4. Although SEP did not seem suitable for producing LWAs according to their particle size and composition (see Section 3.1), both SEP-P-1225 and SEP-PFC-1225 meet the requirements of the LWA standards. Thus, they comply with $\rho_{\mathrm{B}}<1.20 \mathrm{~g} / \mathrm{cm}^{3}$ (0.84 and $0.82 \mathrm{~g} / \mathrm{cm}^{3}$, respectively) and $\rho_{\mathrm{A}}<2.00 \mathrm{~g} / \mathrm{cm}^{3}(1.33$ and $\left.1.37 \mathrm{~g} / \mathrm{cm}^{3}\right)$, as established in EN-13055-1 (57) (Table 4). The average diameter of the aggregates obtained is $7.96 \mathrm{~mm}$ (standard deviation, $\mathrm{sd}=0.24$ ) and $7.93 \mathrm{~mm}(\mathrm{sd}=0.31)$ in SEP-P-1225 and SEPPFC-1225, respectively, which indicates that both types have even experienced slight bloating (BI of 1.02 and $0.58 \%$ ). This implies that real sintering tests are necessary before discarding any raw material for not possessing the best characteristics "on paper".



FIGURE 4. X-ray diffractograms of the unfired material and the sintered aggregates, where SEP-P-1225 and SEP-PFC-1225 diffractograms appear overlapped for being similar. $\mathrm{Q}=$ Quartz; $\mathrm{Pg}=$ Plagioclase; $\mathrm{Fp}=$ Alkali feldspar; $\mathrm{Mc}=\mathrm{Mica} ; \mathrm{Sm}=$ Smectite; $\mathrm{Sp}=$ Sepiolite $; \mathrm{Cal}=$ Calcite $; \mathrm{Dol}=$ Dolomite; Pet $=$ Protoenstatite; $\mathrm{Et}=$ Enstatite; $\mathrm{Dp}=$ Diopside; $\mathrm{G}=\mathrm{Glass} ; \mathrm{Al}=\mathrm{Alumina}$. 



Figure 5. Results obtained from the DSC-TGA tests: (a) SEP; (b) P; (c) FC. DSC: solid line; TGA: dashed line.

It is noteworthy that SEP-P-1225 and SEPPFC-1225 exhibit quite similar properties in all aspects. As can be seen in Figure 6, both aggregates are generally white. The addition of FC has fostered the formation of a black core (Figure 6b) with pores that contain unfired carbon fibers inside (Figure $7 \mathrm{c}$ and Figure $8 \mathrm{~b}$ ). Beyond this, the addition of carbon fiber has not entailed any supplementary benefit, as the similarity between the results of SEP-P-1225 and SEP-PFC-1225 reflects (Table 4). In any case, the fact that FC has not worked with the materials used in this investigation is not an indication that it is an unsuitable additive. Thus, for example, the work previously published by the authors mixing FC with ornamental rock sludge and lower amounts of sepiolite-rich by-products (10), showed excellent results when adding the carbon fiber. This shows that the suitability of such a material in the manufacture of LWAs will depend on the raw materials and the manufacturing conditions, so its effects should be studied on a case-by-case basis.

Apart from the density and bloating results explained above, these two LWAs have similar porosity: $P_{T}, P_{O}$ and $P_{C}$ are close to $50 \%, 15 \%$ and 35 $\%$, respectively. These results are in the same order as some others reported in LWAs also sintered from mineral and carbon fiber wastes (10). A particularity of the SEP-LWAs is that their porosity is uniformly distributed throughout the aggregate inner section, so that, from a structural point of view, there is no clear differentiation between core and shell
(Figure $7 \mathrm{~b}$ and Figure $8 \mathrm{a}, \mathrm{b}$ ). This structure was formed because an adequate viscosity was generated very quickly, so that even part of the gases released in areas close to the surface were trapped, thus avoiding the formation of a non-porous thick shell.

Moderate $\mathrm{WA}_{24}$ results have been recorded (11.84 \% and $9.64 \%$ in Table 4 ), which are significantly lower than others reported in commercial LWAs, for instance, in Arlita G3, whose $\mathrm{WA}_{24}$ is $30.9 \%(9)$. This occurs because the pore interconnection and the shell permeability are not very high ( $P_{O}$ is not either), as rapid firing at high temperatures has favored the formation of closed porosity and a shell which, although thin, is highly vitrified. Some of the water entry routes could be the deep cracks formed along the aggregate surface (Figure 6), which can even extend to the outermost core areas (Figure 7b). The development of these fractures may be related to the high plasticity of the sepiolite raw material and its mixtures (Figure 2), which are located very far from the "acceptable" and "optimal" extrusion zones for ceramics (Figure 2b). In fact, this resulted in the need to use a very high volume of water to shape the pellets (Table 1: $\mathrm{W}_{\mathrm{OP}}$ around $100 \%$ ), which in turn would explain the large shrinkage that the green pellets experienced when oven-dried (23.2\% shrinkage, as indicated in Section 2.4). Equally noteworthy is the high capacity of the dry granules to adsorb hygroscopic moisture from the environment $(\sim 10 \%)$, as explained in Section 2.3. Regarding this aspect, a sudden release of this

TABLE 3. Percentages of mineral and glassy phases detected by Rietveld refined-XRD method (40-42) in the unfired material and the sintered aggregates. $\% \mathrm{P}=$ Percentage of $\mathrm{P}$ in the mixture; $\% \mathrm{FC}=$ Percentage of $\mathrm{FC}$ in the mixture; $\mathrm{t}=\mathrm{Dwell}$ time in the rotary kiln; $\mathrm{T}=$ Firing temperature. $\mathrm{Q}=$ Quartz; $\mathrm{Pg}=$ Plagioclase; $\mathrm{Fp}=$ Alkali feldspar; $\mathrm{Mc}=$ Mica; $\mathrm{Sm}=\mathrm{Smectite} ; \mathrm{Sp}=\mathrm{Sepiolite} ; \mathrm{Cal}=\mathrm{Calcite}$; Dol = Dolomite; Pet = Protoenstatite; Et = Enstatite; $\mathrm{Dp}=$ Diopside; $\mathrm{G}=$ Glass.

\begin{tabular}{|c|c|c|c|c|c|c|c|c|c|c|c|c|c|c|c|c|}
\hline \multirow[b]{2}{*}{ Aggregate name } & \multirow[b]{2}{*}{$\% \mathbf{P}$} & \multirow[b]{2}{*}{$\%$ FC } & \multirow[b]{2}{*}{$t(\min )$} & \multirow[b]{2}{*}{$\mathbf{T}\left({ }^{\circ} \mathrm{C}\right)$} & \multicolumn{12}{|c|}{ Mineralogy (\%) } \\
\hline & & & & & $\mathbf{Q}$ & Pg & $\mathbf{F p}$ & Mc & Sm & Sp & Cal & Dol & Pet & Et & Dp & $\mathbf{G}$ \\
\hline SEP (unfired) ${ }^{\mathrm{a}}$ & 0 & 0 & - & - & 11.1 & 4.3 & 7.9 & 3.9 & 37.8 & 30 & 2.6 & 2.4 & - & - & - & - \\
\hline SEP-P-1225 & 2.5 & 0 & 4 & 1225 & 2.1 & - & - & - & - & - & - & - & 14.2 & 29.1 & 3.6 & 51.1 \\
\hline SEP-PFC-1225 & 2.5 & 2.5 & 4 & 1225 & 2.6 & - & - & - & - & - & - & - & 10.9 & 31.4 & 4.3 & 50.8 \\
\hline
\end{tabular}

${ }^{a}$ Although the mineralogy of SEP (unfired) has been measured in the mixture not containing FC or P, the same results are applicable to the mineral fraction of the mixtures containing these two additives. 
(a)

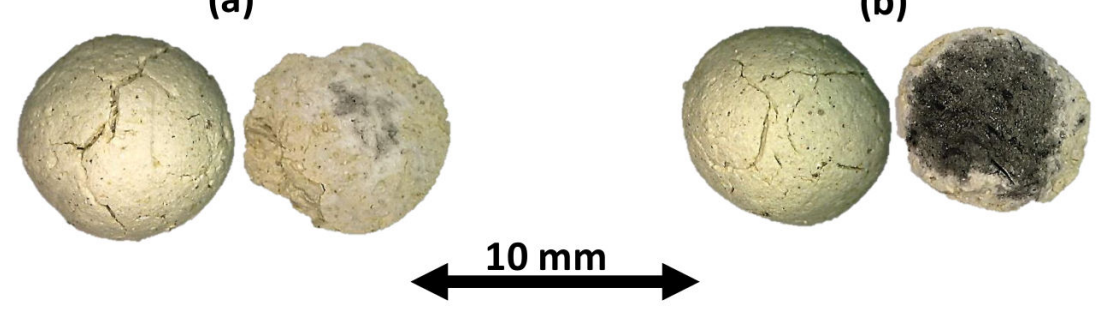

Figure 6. External (left) and internal (right) appearance of sintered LWAs: (a) SEP-P-1225 and (b) SEP-PFC-1225.

water when turned into gas could have encouraged the cracking.

Despite this, the presence of "flaws" in LWAs is not as important as in other ceramic materials where the aesthetics of the pieces is paramount. Indeed, fractures or surface pores could have positive effects in LWAs, for example, by improving bonding with the cement paste when used in lightweight aggregate concrete (58). With respect to the latter, the single aggregate crushing strength $(S)$ is about $6 \mathrm{MPa}$ and the $S / \rho_{\mathrm{A}}$ of 4.3-4.9 $\mathrm{N} / \mathrm{m} \cdot \mathrm{g}$, which are values that exceed those obtained in Argex AR 4/10 - $550\left(S=1.27 \mathrm{MPa}\right.$ and an $\left.S / \rho_{\mathrm{A}}=1.5 \mathrm{~N} / \mathrm{m} \cdot \mathrm{g}\right)$ (11). These results are undoubtedly encouraging if these LWAs are intended for the production of, for example, structural lightweight concrete. However, this can only be reliably demonstrated by an additional study in concrete samples, something that is beyond the scope of this work. The latter is also particularly important because the single aggregate crushing strength test is usually associated with a high dispersion (in this case, sd data are 2.65 and 2.26 for SEP-P-1225 and SEP-PFC-1225, respectively). This confirms that the final evaluation in terms of mechanical strength should be carried out with real concrete specimens, even though, as in this case, the data are promising.

\subsection{Mineralogy, texture and glass formation in the LWAs}

Mineralogical composition is a key factor in aspects such as the appearance of a negative alkalisilica reactivity or the development of a good adhesion between the cement and the aggregate (59, $60)$. Similarly, high proportions of amorphous phase could favor better pozzolanic activity, as well as a reduction in thermal conductivity, which is very interesting from an energy point of view $(61,62)$. The mineralogical composition of the raw material and the sintered LWAs is detailed in Table 3, based on the diffractograms of Figure 4.

TABLE 4. Characteristics of sintered aggregates and unfired pellets. $\% \mathrm{P}=$ Percentage of $\mathrm{P}$ in the mixture; $\% \mathrm{FC}=\mathrm{Percentage}$ of $\mathrm{FC}$ in the mixture; $\mathrm{t}=$ Dwell time; $\mathrm{T}=$ Firing temperature; diam.= Aggregate diameter; $\mathrm{BI}=\mathrm{Bloating}$ index; $\mathrm{LOI}_{\text {firing }}=\mathrm{Loss}_{\mathrm{on}}$ ignition when firing; $\rho_{\mathrm{B}}=$ Loose bulk density; $\rho_{\mathrm{A}}=$ Particle density; $\rho_{\mathrm{S}}=$ Skeleton density; $\rho_{\text {solid }}=$ Relative density of aggregate solid phase; WA ${ }_{24}=$ Water absorption after $24 \mathrm{~h}$ immersion; $P_{T}=$ Total porosity; $P_{O}=$ Open porosity; $P_{C}=$ Closed porosity; $H=$ Void percentage; $S=$ Single particle crushing strength; NA $=$ Not applicable.

\begin{tabular}{|c|c|c|c|c|c|c|c|c|c|c|c|c|c|c|c|c|c|c|}
\hline \multirow[b]{2}{*}{ Name } & \multirow[b]{2}{*}{$\begin{array}{l}\% \\
\mathbf{P}\end{array}$} & \multirow[b]{2}{*}{$\begin{array}{c}\% \\
\text { FC }\end{array}$} & \multirow[b]{2}{*}{$\begin{array}{c}\mathbf{t} \\
(\min )\end{array}$} & \multirow[b]{2}{*}{$\begin{array}{c}\mathbf{T} \\
\left({ }^{\circ} \mathrm{C}\right)\end{array}$} & \multirow[b]{2}{*}{$\begin{array}{l}\text { diam. } \\
(\mathrm{mm})\end{array}$} & \multirow[b]{2}{*}{$\begin{array}{c}\text { BI } \\
(\%)\end{array}$} & \multirow[b]{2}{*}{$\begin{array}{c}\mathbf{L O I}_{\text {firing }} \\
(\%)\end{array}$} & \multicolumn{4}{|c|}{ Density, $\rho\left(\mathrm{g} / \mathrm{cm}^{3}\right)$} & \multirow[b]{2}{*}{$\begin{array}{l}\mathrm{WA}_{24} \\
(\%)\end{array}$} & \multicolumn{3}{|c|}{ Porosity, P (\%) } & \multirow[b]{2}{*}{$\begin{array}{c}H \\
(\%)\end{array}$} & \multirow[b]{2}{*}{$\begin{array}{c}S \\
\text { (MPa) }\end{array}$} & \multirow[b]{2}{*}{$\begin{array}{c}S / \rho_{A} \\
(N / m \cdot g)\end{array}$} \\
\hline & & & & & & & & $\rho_{\mathrm{B}}$ & $\boldsymbol{\rho}_{\mathrm{A}}^{\mathrm{b}}$ & $\boldsymbol{\rho}_{\mathrm{s}}^{\mathrm{c}}$ & $\boldsymbol{\rho}_{\text {solid }}{ }^{d}$ & & $P_{\mathrm{T}}$ & $P_{\mathrm{o}}$ & $P_{\mathrm{C}}$ & & & \\
\hline SEP-P-1225 & 2.5 & 0 & 4 & 1225 & 7.96 & 1.02 & 14.58 & 0.84 & 1.33 & 1.58 & 2.61 & 11.84 & 49.15 & 15.75 & 33.40 & 67.74 & 6.48 & 4.88 \\
\hline SEP-PFC-1225 & 2.5 & 2.5 & 4 & 1225 & 7.93 & 0.58 & 17.11 & 0.82 & 1.37 & 1.58 & 2.63 & 9.64 & 47.80 & 13.27 & 34.53 & 68.99 & 5.93 & 4.32 \\
\hline SEP-Pa & 2.5 & 0 & $48 \mathrm{~h}^{\mathrm{a}}$ & $105^{\mathrm{a}}$ & 7.88 & 0 & 0 & 0.97 & NA & NA & NA & NA & NA & NA & NA & NA & 4.67 & NA \\
\hline SEP-PFC ${ }^{a}$ & 2.5 & 2.5 & $48 \mathrm{~h}^{\mathrm{a}}$ & $105^{\mathrm{a}}$ & 7.88 & 0 & 0 & 0.99 & NA & NA & NA & NA & NA & NA & NA & NA & 3.34 & NA \\
\hline
\end{tabular}

${ }^{\text {a }}$ Unfired pellet, so that $\mathrm{t}$ and T refers to oven-dry conditions $\left(48\right.$ hours at $\left.105{ }^{\circ} \mathrm{C}\right)$ prior to start the actual firing stage in the rotary kiln.

${ }^{\mathrm{b}} \rho_{\mathrm{A}}$ is equivalent to the parameter called "oven dry density" $\left(\rho_{\mathrm{Lrd}}\right)$ in the Annex C of the standard EN-1097-6 (34).

${ }^{c} \rho_{\mathrm{S}}$ is equivalent to the parameter called "apparent density" $\left(\rho_{\mathrm{La}}\right)$ in the Annex C of the standard EN-1097-6 (34).

${ }^{\mathrm{d}} \rho_{\text {solid }}$ is equivalent to the parameter called $\rho_{\text {matrix }}$ in other previous publications $(9,10,35)$. The reason of this change is to avoid any confusion with the term "matrix" related to textural characteristics. 
(9)

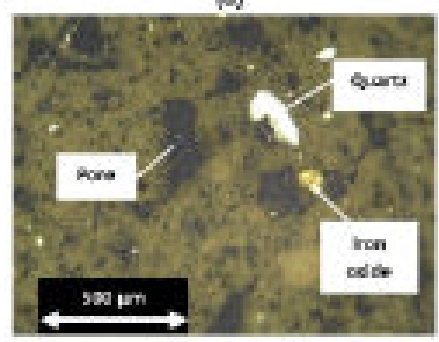

(b)

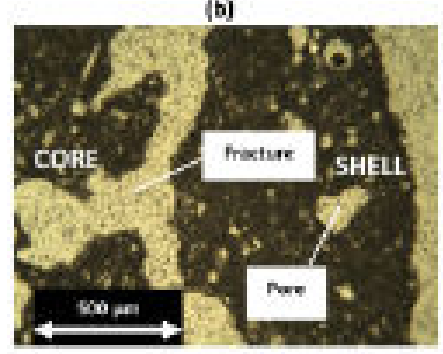

(c)

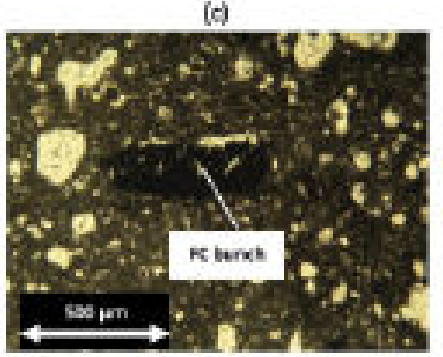

Figure 7. Pictures taken through Thin-Section Polarized Light Microscopy using PP or CP at 50x: (a) core-area in SEP-P-1225 with CP; (b) PP detail view of a macrofracture located in the shell-core border of SEP-P-1225; (c) PP detail view of a bunch of carbon fibers inside a large pore in the core of SEP-PFC-1225.

\subsubsection{Mineralogy and texture of the aggregates produced in this study}

The mineralogy of SEP-P-1225 and SEPPFC-1225 is similar (Figure 4; Table 3), so the addition of FC has not meant any significant effect in this facet either. Considering the original mineralogy, only small proportions of quartz have withstood the firing process $(2.1$ and $2.6 \%$ in the aggregates against $11.1 \%$ in the unfired material), as shown in Table 3. Quartz has appeared in the form of isolated phenocrysts embedded in a porous aphanitic matrix to give rise to a porphyritic texture (Figure 7a). Other relatively large bodies are iron oxides whose structure is crystalline and paracrystalline according to TSPLM observations through CP (Figure 7a). According to Table 3, the groundmass surrounding these crystals would be mainly composed of glass $(\sim 51 \%)$ as well as tiny neo-formed crystals of enstatite $(\sim 30 \%)$, protoenstatite (10.9 $14.2 \%)$ and diopside $(\sim 4 \%)$. Enstatite crystallized at $850^{\circ} \mathrm{C}$ approximately (sharp exothermic peak in Figure 5a), just after the total escape of $\mathrm{OH}$ groups and lattice destruction of the sepiolite clay minerals were produced (sharp endothermic peak at $\sim 835^{\circ} \mathrm{C}$ in Figure 5a) $(1,2,47)$. Although the DSC crystallization peak of protoenstatite has not been detected in Figure 5a, this mineral was probably generated at about $970^{\circ} \mathrm{C}$ from the enstatite transformation (2).

The detection of diopside is also reported in other studies related to LWA manufacturing from wastes $(63,64)$. Although there is not a clear endothermicexothermic peak system in Figure 5a that relates glass-transition and crystallization temperatures to diopside (probably due to its low concentration), this mineral could have crystallized at approximately $850-950^{\circ} \mathrm{C}$ based on bibliographic data (65).

\subsubsection{Microtexture and microstructures}

Since the neo-formed pyroxenes require lower crystallization temperatures than those used inside the kiln, it is likely that they crystallized during the final cooling phase and especially during the initial heating (which may be slower than the final cooling).

This process would be somewhat similar to what happens when lava cools suddenly, generating what is known as a strong undercooling, which leads to the development of a large number of nuclei containing very small crystals (66). This is consistent with Figure 8c, where a highly porous and amorphous microstructure can be seen, in which the crystals are so small that they are difficult to be detected.


FIGURE 8. Scanning Electron Microscopy pictures of: (a) entire cross-section of SEP-P-1225, x11; (b) shell-core area in SEP-PFC-1225, x65; (c) core pores containing microspheres in SEP-PFC-1225, x2000. 
The use of FC as an additive has led to the formation of microspheres (Figure 8c). This type of structure has been previously identified in other studies related to the addition of carbon fiber in LWAs manufactured with mineral residues as main components and sepiolite as an additive $(11,38)$. This suggests that the addition of carbon fiber promotes the formation of microspheres in those areas where carbon fibers are embedded or have been burnt.

\section{CONCLUSIONS}

The production of lightweight aggregates using sepiolite plant rejects (SEP) as the main component has been assessed. The effect of plastic (P) and carbon fiber (FC) wastes when added in low proportions to SEP has also been studied.

The main conclusions that can be drawn are summarized below:

- Although its composition and particle size is theoretically inadequate according to the Riley (24) and Cougny (46) diagrams, the sepioliterich by-product under study has been demonstrated to have a great potential to be artificially sintered into LWAs in practice. Its harnessing as the main component in the mixture has resulted in the development of LWAs with technological characteristics that not only meet the international requirements in terms of density, but also exhibit porosity, surface characteristics and mechanical strength which are expected to be very positive if applied, for example, to lightweight concrete production.

- Despite the above, the high plasticity of sepiolite requires the addition of some gas-pressure mitigating additive ( $\mathrm{P}$ and $\mathrm{FC}$ in the present investigation) to avoid the bursting of the pellets when placed in the kiln. However, other more conventional degreaser components should be tested in future investigations.

- Apart from the decomposition of P and FC, the processes of clay mineral dehydroxilation and water release could be important in the formation of pores.

- In terms of the changes that have occurred in mineralogy and texture, it is worth highlighting the important development of amorphous phase in the aggregates $(>50 \%)$ together with the neoformation of pyroxenes (enstatite, protoenstatite and diopside). Quartz was the only inherited specie, appearing in the form of isolated phenocrysts within a generally porphyritic porous texture.

In conclusion, the use of sepiolite as the major component in LWA manufacturing can be an excellent alternative for harnessing this material in a different way, especially from those plant processed fractions that are "unmarketable". Thanks to this new perspective these materials can be valorized, meaning an additional economic and environmental asset.

\section{ACKNOWLEDGEMENTS}

This research has been supported by the research project PEII-2014-025-P of the Junta de Comunidades de Castilla-La Mancha (JCCM) and the $\mathrm{PhD}$ grant number PRE-7911/2014 whose funds come from the Consejería de Educación, Cultura y Deportes of JCCM and the European Social Fund (DOCM 2014/10620 and DOCM 2016/12998 BDNS (Identif.): 323799). Special thanks to Tolsa, Innovarcilla and ICSA-Aernnova, the companies that have provided us the raw materials, without which this study would not have been possible.

\section{REFERENCES}

1. Goktas, A.A.; Misirli, Z.; Baykara, T. (1997) Sintering behaviour of sepiolite. Ceram. Int. 23, 305-311. https:// doi.org/10.1016/S0272-8842(96)00023-5.

2. Zhang, Y.; Wang, L.; Wang, F.; Liang, J.; Ran, S.; Sun, J. (2017) Phase transformation and morphology evolution of sepiolite fibers during thermal treatment. Appl. Clay Sci. 143, 205-211. https://doi.org/10.1016/j.clay.2017.03.042.

3. Pascual, C.; Criado, E.; Recio, P.; Martínez, R.; De Aza, A.H.; Valle, F.J.; Mañueco, C. (2011) La porcelana de sepiolita de Bartolomé Sureda (1802-1808). Investigación arqueométrica sobre la Real Fábrica de Buen Retiro. Bol. Soc. Esp. Ceram. Vidrio. 50 [6], 311-328. https://doi.org/ 10.3989/cyv.402011.

4. Ran, S-s.; Wang. L-j.; Zhang, Y-d.; Liang, J-s. (2016) Reinforcement of bone china by the addition of sepiolite nano-fibers. Ceram. Int. 42, 13485-13490. https://doi.org/ 10.1016/j.ceramint.2016.05.140.

5. Li, J.; Liang, J.; Wang, F.; Wang, L. (2015) Effect of sepiolite fibers addition on sintering behavior of sanitary bodies. Appl. Clay Sci. 105-106, 231-235. https://doi.org/ 10.1016/j.clay.2014.10.017.

6. Noda, H.; Miyagawa, K.; Kobayashi, M.; Horiguchi, H.; Ozawa, K.; Kumada, N.; Yonesaki, Y.; Takei, T.; Kinomura, N. (2009) Preparation of cordierite from fibrous sepiolite. J. Ceram. Soc. Jpn. 117 [1371] 1236-1239. https://doi.org/10.2109/jcersj2.117.1236.

7. Zhou, J-e.; Dong, Y.; Hampshire, S.; Meng, G. (2011) Utilization of sepiolite in the synthesis of porous cordierite ceramics. Appl. Clay Sci. 52 [3], 328-332. https://doi.org/ 10.1016/j.clay.2011.02.001.

8. Suárez, S.; Coronado, J.M.; Portela, R.; Martín, J.C; Yates, M.; Avila, P.; Sánchez B. (2008) On the preparation of $\mathrm{TiO}_{2}$-sepiolite hybrid materials for the photocatalytic degradation of TCE: influence of $\mathrm{TiO}_{2}$ distribution in the mineralization. Environ. Sci. Technol. 42 [16], 5892-5896. https://doi.org/10.1021/es703257w.

9. Moreno-Maroto, J.M.; González-Corrochano, B.; AlonsoAzcárate, J.; Rodríguez, L.; Acosta, A. (2017) Development of lightweight aggregates from stone cutting sludge, plastic wastes and sepiolite rejections for agricultural and environmental purposes. J. Environ. Manage. 200, 229-242. https://doi.org/10.1016/j.jenvman. 2017.05.085.

10. Moreno-Maroto, J.M; González-Corrochano, B.; AlonsoAzcárate, J.; Rodríguez, L.; Acosta, A. (2017) Manufacturing of lightweight aggregates with carbon fiber and mineral wastes. Cem. Concr. Compos. 83, 335-348. https://doi.org/10.1016/j.cemconcomp.2017.08.001. 
11. Moreno-Maroto, J.M.; González-Corrochano, B.; AlonsoAzcárate, J.; Martínez García, C. (2019) A study on the valorization of a metallic ore mining tailing and its combination with polymeric wastes for lightweight aggregates production. J. Cleaner Prod. 212, 997-1007. https://doi.org/10.1016/j.jclepro.2018.12.057.

12. Murray, H.H.; Pozo, M.; Galán, E. (2011) An introduction to palygorskite and sepiolite deposits-location, geology and uses. In: Galán, E., Singer, A. (Eds.), Developments in Palygorskite-Sepiolite Research. A New Outlook on These Nanomaterials. Developments in Clay Science. 3, 85-99. Elsevier, Amsterdam. https://doi.org/10.1016/B978-0-44453607-5.00004-9.

13. Estadística Minera de España (2016) Gobierno de España. Ministerio de Energía, Turismo y Agenda Digital. Secretaría de Estado. Dirección General de Política Energética y Minas. (Mining Statistics of Spain in 2016, Spanish Government).

14. BGS (2018) World Mineral Production 2012-2016. Brithish Geological Survey, Natural Evironmental Research Council. ISBN:978-0-85272-882-6 (website version).

15. European Commission (2014) Commission Decision 2014/955/EU of 18 December 2014 amending Decision $2000 / 532 / \mathrm{EC}$ on the list of waste pursuant to Directive 2008/98/EC of the European Parliament and of the Council Text with EEA relevance. Official Journal of the European Union, 30/12/2014

16. Yasuda, Y. (1991) Sewage-sludge utilization in Tokyo. Water Sci. Technol. 23 [10-12], 1743-1752. https://doi.org/ 10.2166/wst.1991.0629.

17. De Santiago Buey, C.; Raya García, M. (2008) Análisis del peso específico y porosidad de materiales porosos mediante picnometría de helio. Ing. Civil. 151, 95-103. ISSN 0213-8468.

18. Buurman, P.; Pape, Th.; Reijneveld, J. A.; de Jong, F.; van Gelder, E. (2001) Laser-diffraction and pipette-method grain sizing of Dutch sediments: correlations for fine fractions of marine, fluvial, and loess samples. Neth. J. Geosci. 80 [2], 49-57. https://doi.org/10.1017/S001677460 0022319 .

19. Eshel, G.; Levy, G.J; Mingelgrin, U.; Singer, M.J. (2004) Critical evaluation of the use of laser diffraction for particle-size distribution analysis. Soil Sci. Soc. Am. J. 68 [3], 736-743. https://doi.org/10.2136/sssaj2004.7360.

20. Ferro, V.; Mirabile, S. (2009) Comparing particle size distribution analysis by sedimentation and laser diffraction method. J. Ag. Eng. - Riv. Ing. Agr. 2, 35-43. https://doi.org/ 10.4081/jae.2009.2.35

21. EN-933-9 (1999) Tests for geometrical properties of aggregates. Part 9: Assessment of fines. Methylene blue test. European Committee for Standardization.

22. Santamarina, J.C.; Klein, K.A.; Wang, Y.H.; Prencke, E. (2002) Specific surface: determination and relevance. Can Geotech. J. 39 [1], 233-241. https://doi.org/10.1139/t01 -077 .

23. Ingamells, C.O. (1970) Lithium metaborate flux in silicate analysis. Anal. Chim. Acta. 52, 323-334. https://doi.org/ 10.1016/S0003-2670(01)80963-6.

24. Riley, C.M. (1951) Relation of chemical properties to the bloating of clays. J. Am. Ceram. Soc. 34 [4], 121-128. https://doi.org/10.1111/j.1151-2916.1951.tb11619.x.

25. Fakhfakh, E.; Hajjaji, W.; Medhioub, M.; Rocha, F.; LópezGalindo, A.; Setti, M.; Kooli, F.; Zargouni, F.; Jamoussi, F. (2007) Effects of sand addition on production of lightweight aggregates from Tunisian smectite-rich clayey rocks. Appl. Clay Sci. 35 [3-4], 228-237. https://doi.org/ 10.1016/j.clay.2006.09.006.

26. UNE 103-103-94 (1994) Determinación del límite líquido de un suelo por el método del aparato de Casagrande. Asociación Española de Normalización y Certificación AENOR Norma española.

27. Moreno-Maroto, J.M.; Alonso-Azcárate, J. (2015) An accurate, quick and simple method to determine the plastic limit and consistency changes in all types of clay and soil: The thread bending test. Appl. Clay Sci. 114, 497-508. https://doi.org/10.1016/j.clay.2015.06.037.
28. Moreno-Maroto, J.M.; Alonso-Azcárate, J. (2016) A bending test for determining the atterberg plastic limit in soils. J. Vis. Exp. 112, e54118. https://doi.org/ $10.3791 / 54118$.

29. Moreno-Maroto, J.M.; Alonso-Azcárate, J. (2017) Plastic limit and other consistency parameters by a bending method and interpretation of plasticity classification in soils. Geotech. Test. J. 40 [3], 467-482. https://doi.org/ 10.1520/GTJ20160059.

30. ASTM D 4318-10e1 (2014) Standard test methods for liquid limit, plastic limit, and plasticity index of soils. Annual Book of ASTM Standards, ASTM International, West Conshohocken, PA.

31. Moreno-Maroto, J.M.; Alonso-Azcárate, J. (2018) What is clay? A new definition of "clay" based on plasticity and its impact on the most widespread soil classification systems. Appl. Clay Sci. 161, 57-63. https://doi.org/10.1016/ j.clay.2018.04.011.

32. Gippini, E. (1969) Contribution à l'étude des proprietés de molage des argiles et des mélanges optimaux de matières premières. L'Indus. Céram. 619, 423-435.

33. EN-1097-3 (1998) Tests for mechanical and physical properties of aggregates. Part 3: Determination of loose bulk density and voids. European Committee for Standardization.

34. EN-1097-6 (2013) Tests for mechanical and physical properties of aggregates. Part 6: Determination of particle density and water absorption. European Committee for Standardization.

35. Bernhardt, M.; Tellesbø, H.; Justnes, H.; Wiik, K. (2013) Mechanical properties of lightweight aggregates. J. Eur. Ceram. Soc. 33, 2731-2743. https://doi.org/10.1016/ j.jeurceramsoc.2013.05.013.

36. Yashima, S.; Kanda, Y.; Sano, S. (1987) Relationship between particle size and fracture energy or impact velocity required to fracture as estimated from single particle crushing. Powder Technol. 51 [3], 277-282. https://doi.org/ 10.1016/0032-5910(87)80030-X

37. Li, Y.; Wu, D.; Zhang, J.; Chang, L.; Dihua, W.; Fang, Z.; Shi, Y. (2000) Measurement and statistics of single pellet mechanical strength of differently shaped catalysts. Powder Technol. 113 [1-2], 176-184. https://doi.org/10.1016/ S0032-5910(00)00231-X

38. Moreno-Maroto, J.M.; González-Corrochano, B.; AlonsoAzcárate, J.; Rodríguez, L.; Acosta, A. (2018) Assessment of crystalline phase changes and glass formation by Rietveld-XRD method on ceramic lightweight aggregates sintered from mineral and polymeric wastes. Ceram. Int 44, 11840-11851. https://doi.org/10.1016/ j.ceramint.2018.03.274.

39. NIST (2012) Certificate of analysis. Standard reference material 676a. Alumina powder for quantitative analysis by X-ray diffraction. National Institute of Standards and Technology.

40. Bish, D.L.; Post, J.E. (1993) Quantitative mineralogical analysis using the Rietveld full pattern fitting method. Am. Mineral. 78, 932-940.

41. Yasukawa K; Terashi, Y; Nakayama, A. (1998) Crystallinity analysis of glass-ceramics by the Rietveld method. J. Am. Ceram. Soc. 81 [11] 2978-2982. https:// doi.org/10.1111/j.1151-2916.1998.tb02723.x.

42. De la Torre, A.G.; Bruque, S.; Aranda, M.A.G (2001) Rietveld quantitative amorphous content analyses. J. Appl. Crystallogr. 34 [2], 196-202. https://doi.org/10.1107/S002 1889801002485

43. Raith, M.M.; Raase, P.; Reinhardt, J. (2012) Guide to thin section microscopy. Second Edition. ISBN 978-3-00037671-9 (PDF) (2012)

44. Barnes, G.E. (2013) An apparatus for the determination of the workability and plastic limit of clays. Appl. Clay Sci. 80-81, 281-290. https://doi.org/10.1016/j.clay.2013.04.014.

45. Moreno-Maroto, J.M; Cobo-Ceacero, C.J.; UcedaRodríguez, M.; Cotes-Palomino, T.; Martínez García, C.; Alonso-Azcárate, J. (2020) Unraveling the expansion mechanism in lightweight aggregates: Demonstrating that bloating barely requires gas. Constr. Build. Mater. 247, 
118583. https://doi.org/10.1016/j.conbuildmat.2020.11 8583.

46. Cougny, G. (1990) Specifications for clayey raw materials used to produce expanded lightweight aggregates. Bull. Int. Assoc. Eng. Geol. 41, 47-55. https://doi.org/10.1007/BF02 590206.

47. Földvári, M. (2011) Handbook of thermogravimetric system of minerals and its use in geological practice. Occasional Papers of the Geological Institute of Hungary. Geological Institute of Hungary. Volume 213. (2011)

48. Heller-Kallai, L.; Miloslavski, I.; Grayevsky, A. (1989) Evolution of hydrogen on dehydroxylation of clay minerals. Am. Mineral. 74, 818-320.

49. Mathur, A.; Varma, I.K. (1992) Effect of structure on thermal behaviour of nadimide resins: 1. Polymer. 33 [22], 4845-4850. https://doi.org/10.1016/0032-3861(92)90701$\mathrm{W}$.

50. Piquero, T.; Vincent, H.; Vincent, C.: Bouix, J. (1995) Influence of carbide coatings on the oxidation behavior of carbon fibers. Carbon. 33 [4], 455-467. https://doi.org/ 10.1016/0008-6223(94)00170-5.

51. Mourad, A-H.I.; Akkad, R.O.; Soliman, A.A.; Madkour, T.M. (2009) Characterisation of thermally treated and untreated polyethylene-polypropylene blends using DSC, TGA and IR techniques. Plast. Rubber Compos. 38 [7], 265-278. https://doi.org/10.1179/146580109X12473409436 625.

52. Selladurai, M.; Sundararajan, P.R.; Sarojadevi, M. (2012) Synthesis, thermal and mechanical properties of modified PMR/carbon fiber composites. Chem. Eng. J. 203, 333-347. https://doi.org/10.1016/j.cej.2012.06.049.

53. Kim, J.; Moon, T.J.; Howell, J.R. (2002) Cure kinetic model, heat of reaction, and glass transition temperature of AS4/3501-6 graphite-epoxy prepregs. J. Compos. Mater. 36 [21], 2479-2498. https://doi.org/10.1177/002199830203602 1712

54. Liu, W.; Varley, R.J.; Simon, G.P. (2007) Understanding the decomposition and fire performance processes in phosphorus and nanomodified high performance epoxy resins and composites. Polymer. 48 [8], 2345-2354. https:// doi.org/10.1016/j.polymer.2007.02.022.

55. Li, S.; Zhang, Y.M.; Zhou, Y.F. (2012) Preparation and characterization of sol-gel derived zirconia coated carbon fiber. Surf. Coat. Technol. 206 [23], 4720-4724. https:// doi.org/10.1016/j.surfcoat.2012.01.037.

56. Conley, J.E.; Wilson, H.; Kleinfelter, T.A.; and others (1948) Production of lightweight concrete aggregates from clays, shales, slates and other materials. US Bureau of mines report of investigation, 4401, $121 \mathrm{pp}$.

57. EN-13055-1 (2002) Lightweight aggregates. Part 1: Lightweight aggregates for concrete, mortar and grout. European Committee for Standardization.

58. Lo, T.Y.; Cui, H.Z. (2004) Effect of porous lightweight aggregate on strength of concrete. Mater. Lett. 58 [6], 916-919. https://doi.org/10.1016/j.matlet.2003.07.036.

59. Soriano-Carrillo, J. (1980) Influencia de la naturaleza mineralógica de las adiciones en el comportamiento de la pasta endurecida del cemento Portland. Rev. Obras Públ. 127 [3186], 861-867.

60. Gadea, J.; Soriano, J.; Martín, A.; Campos, P.L.; Rodríguez, A.; Junco, C.; Adán, I.; Calderón, V. (2010) The alkali-aggregate reaction for various aggregates used in concrete. Mater. Construcc. 60 [299], 69-78. https://doi.org/ 10.3989/mc.2010.48708

61. Wasserman, R.; Bentur, A. (1997) Effect of lightweight fly ash aggregate microstructure on the strength of concretes. Cem. Concr. Res. 27 [4], 525-537. https://doi.org/10.1016/ S0008-8846(97)00019-7.

62. Nguyen, L.H.; Beaucour, A-L.; Ortola, S.; Noumowé, A. (2014) Influence of the volume fraction and the nature of fine lightweight aggregates on the thermal and mechanical properties of structural concrete. Constr. Build. Mater. 51, 121-132. https://doi.org/10.1016/j.conbuildmat.2013.11. 019 .

63. Kourti, I.; Cheeseman, C.R. (2010) Properties and microstructure of lightweight aggregate produced from lignite coal fly ash and recycled glass. Resour. Conserv. Recycl. 54 [11], 769-775. https://doi.org/10.1016/j.rescon rec.2009.12.006.

64. González-Corrochano, B.; Alonso-Azcárate, J.; Rodas, M.; Luque, F.J.; Barrenechea, J.F. (2010) Microstructure and mineralogy of lightweight aggregates produced from washing aggregate sludge, fly ash and used motor oil. Cem. Concr. Compos. 32 [9], 694-707. https://doi.org/10.1016/ j.cemconcomp.2010.07.014.

65. Erol, M.; Küçükbayrak, S.; Ersoy-Meriçboyu, A.; Öveçoḡlu, M.L. (2001) Crystallization behaviour of glasses produced from fly ash. J. Eur. Ceram. Soc. 21, 2835-2841. https://doi.org/10.1016/S0955-2219(01)00221-7.

66. Swanson, S.E. (1977) Relation of nucleation and crystalgrowth rate to the development of granitic textures. $\mathrm{Am}$. Mineral. 62 [9-10] 966-978. 